\title{
EFEK HAMBATAN EKSTRAK DAUN CEPLUKAN (Physalis minima L) TERHADAP KONTRAKTILITAS OTOT POLOS USUS HALUS TERPISAH MARMUT DENGAN STIMULASI METAKOLIN EKSOGEN
}

\section{THE INHIBITION EFFECT OF Physalis minima LEAF TOWARD THE GUINEA PIG'S ISOLATED ILEUM SMOOTH MUSCLE CONTRACTILITY WHICH STIMULATED BY EXOGEN METACHOLINE}

\author{
Citra Tarannita*, Nur Permatasari**, Sudiarto *** \\ ${ }^{*}$ Program Studi Pendidikan Dokter Fakultas Kedokteran Unibraw Malang \\ ** Laboratorium Farmakologi Fakultas Kedokteran Unibraw Malang \\ ** Laboratorium Fisiologi Fakuktas Kedokteran Unibraw Malang
}

\begin{abstract}
Physalis sp. has lots of merits as a kind of traditional medicine and one of them is its function as an alternatif treatment for diarrhea. Physalis minima leaf contains alkoloid atropine which is assumed can inhibit the contraction of guinea pig's isolated ileum smooth muscle. This research was to know the effect of Physalis minima leaf extract toward the contraction of small intestine smooth muscle. This research was an experimental study using "The Post Control Group Design", and guinea pig's isolated ileum as samples. The samples consisted of five guinea pigs, each sample was given four kinds of treatment. The control was given metacholine at the dose of $10^{-5}$ without Physalis minima leaf extract. Before giving metacholine at the dose of $10^{-5}$, the samples were given the first dosage of Physalis minima leaf extract $(0.15 \%)$, the second dose $(0.30 \%)$ and the third dose $(0.45 \%)$ so getting four graphs for each sample. The level of contraction was recorded by using kymograph. The result showed that the ileum contraction of the third group was inhibited (One Way ANOVA, $p=0.041$ ), and there was a relation between the increasing dosage of Physalis minima leaf extract and the decreasing ileum contraction (simple linear regression, with $R=-0.608 p=0.04$ and regression equation $y=52.150$ 7.660x). The conclusion of this research is that the Physalis minima leaf extract can inhibit the contraction of guinea pig's isolated ileum smooth muscle. This contraction inhibition happens because Physalis monoma leaf extract contrains the alkaloid atropine which is presumed to work on the muscarinic receptors in the ileum smooth muscle. Further studies is needed to discover the definite mechanism of Physalis minima leaf extract in dereasing the contraction of ileum smooth muscle.
\end{abstract}

Key words: Physalis minima leaf Extract, Ileum Smooth Muscle's Contraction

\section{PENDAHULUAN}

Diare merupakan masalah kesehatan masyarakat yang utama di Indonesia dan menjadi salah satu dari tiga penyebab kunjungan utama ke Puskesmas. Dari hasil Survei Kesehatan Rumah Tangga tahun 1997 didapatkan angka kesakitan akibat diare sebesar 20,27 per 1000 penduduk dan angka kematian (CFR) akibat diare sebesar 0,008 per 100 penduduk (1).

Penelitian dalam tahun-tahun terakhir menunjukkan bahwa penyebab utamanya adalah bertumputknya cairan di usus akibat terganggunya resorbsi air atau / dan terjadinya hipersekresi. Pada keadaan normal, resorbsi melebihi sekresi, tetapi karena sesuatu sebab sekresi menjadi lebih besar daripada resorbsi, maka terjadilah diare akibat virus, diare bakterial (invasif), diare parasiter, diare akibat enterotoksin dan diare akibat yang lain seperti alergi dan

Jurnal Kedokteran Brawijaya, Vol. XXII, No.1, April 2006

Korespondensi: Nur Permatasari; Laboratorium Farmakologi Fakultas Kedokteran Unibraw; Jl. Veteran Malang 65145; Telp. (0341) 580993 ext. 110 pengaruh psikis (2). Walaupun penyebab utama diare bermacam-macam, selain rehidrasi dan pemberian obat sesuai etiologinya, dalam beberapa kasus perlu diberikan obstipansia untuk terapi simptomatis yang dapat menghentikan diare, yaitu melelui zat-zat penekan peristaltik sehingga memberikan lebih banyak waktu untuk resobsi air dan elektrolit oleh mukosa usus (2).

Semakin berkembangnya jenis obat-obatan untuk mengobati diare, yang makin membuat biaya semakin mahal, maka diperlukan suatu bahan berkhasiat yang dalam kehidupan sehari-hari mudah didapat, murah, cukup berkhasiat dan efek sampingnya tidak sebesar obat-obat sintetis. Hal ini di dukung pula oleh suatu paradigma baru dibidang kesehatan, yaitu "Back to nature" (kembali ke alam). Dari kenyataan-kenyataan tersebut, maka merupakan tuntutan bagi kita untuk selalu mengadakan penelitian-penelitian ilmiah terhadap sumber-sumber alam khususnya tanaman-tanaman yang berkhasiat sebagai obat. 
Dari hasil penelitan Mulchandani dkk (1979), diketahui bahwa tanamaan Physalis minima $L$ mengandung senyawa-senyawa steroid yang diberi nama fisalin $A$, fisalin $B$, fisalin $C$, fisalin $D$, wita fisalin A, wita fisalin $C$ dan 5,6 epoksi fisalin B. Kandungan kimia lain yang teramati ada dalam tanaman ini adalah senyawa golongan polifenol pada akar, batang dan daun. Berdasarkan pemeriksaan total, tanaman ini mengandung unsur kalium, magnesium dan besi (3). Selain itu tanaman dari family solanaceae dapat memproduksi berbagai macam alkaloid. Dari berbagai genus yang berbeda tetapi family yang sama kemungkinan akan mengandung suatu alkaloid yang sama (4). Pada penelitian Efendi (1998), ditemukan alkaloid pada daun Physalis minima $L$ yang terbagi menjadi fraksi $A$, $B$, dan $C$. Fraksi $C$ menunjukkan harga $\mathrm{Rf}$ yang hampir sama dengan standart Belladona yang mengandung antara lain alkaloid atropin dan scopolamine (5).

Adanya berbagai kandungan kimia pada dun Physalis minima $L$ dan penggunaan secara empiris Physalis angulata, yang memiliki kandungan aklaloid yang sama dengan Physalis minima $L$, sebagai obat untuk diare mendorong dilakukannya penelitian ini mengingat sampai saat ini penelitian tentang efek ekstrak daun ceplukan terhadap kontraktilitas usus belum pernah dilakukan di Indonesia. Oleh karena itu, penelitian ini bertujuan untuk mengungkap efek ekstrak daun ceplukan (Physalis minima L) terhadap pergerakan otot polos usus halus terpisah marmut (Cavia porcellus).

\section{METODE}

Rancangan penelitian yang digunakan dalam penelitian ini adalah studi eksperimental laboratorium dengan pendekaan post control group design dengan mengukur efek pemberian ekstrak daun Physalis minima $L$ terhadap kontraktilitas otot polos usus halus terpisah marmut.

Organ yang digunakan pada penelitian ini adalah usus halus marmut bagian ileum karena relatif lebih tahan terhadap trauma dan kontraksinya lebih kuat daripada jejunum atau duodenum (6). Untuk mendapatkan kontraksi, pada penelitian ini akan digunakan metakolin karena metakolin mempunyai kekuatan yang sama dengan asetilolin terhadap reseptor kolinergik, tidak cepat dihidrolisa oleh asetikholinesterase sehingga efeknya bertahan lama dan tidak cepat kembali ke baseline (7).

\section{Ekstraksi daun Physalis minima $L$}

Bubuk kering (simplisia) Physalis minima $L$ diperoleh dari balai tanaman obat Materia Medika Kotatif Batu Malang. Bubuk kering (simplisia) 200 gram dibungkus dengan kertas saring dan direndam sehari semalam dengan etanol absolut. Hasil rendaman kemudian dimasukkan ke dalam sokhlet $250 \mathrm{ml}$. Di bagian bawah sokhlet dipasang labu pelarut yang telah diisi beberapa butir porselen sebagai isolator panas. Setelah pendingin dipasang, air dialirkan ke pendingin tersebut melalui kran lalu water bath dinyalakan agar labu menjadi panas. Pada saat etanol mendidih akan terjadi kondensasi uap etanol ke dalam pendingin. Tetesan etanol tersebut akan memenuhi sokhlet sehingga mencapai ketinggian tertentu kemudian destilat etanol akan turun ke dalam labu. Jika cairan dalam sokhlet ini sudah jernih, proses ekstraksi dihentikan. Setelah dingin, destilat etanol dimasukkan ke dalam rotary evaporator vakum dan dilakukan penguapan hingga pelarut etanol terpisah adari minyak ceplukan. Setelah diuapkan, minyak ceplukan murni dipanaskan dalam oven pada suhu $70^{\circ} \mathrm{C}$ untuk menghilangkan sisa-sisa pelarut etanol yang mungkin masih tertinggal di dalam minyak ceplukan.

\section{Preparasi Organ Terpisah}

Marmut yang sebelumnya telah dipuasakan selama 10-12 jam dieksekusi dengan cara dislokasi tulang leher kemudian adomennya dibuka dan caecumnya diangkat ke depan maka ileum akan ditemukan tergabung pada bagian belakangnya. lleum dipotong $5 \mathrm{~cm}$ dari caecum sepanjang 2 $\mathrm{cm}$ kemudian dimasukkan dalam cawan petri yang berisi larutan Kreb's. Agar tidak rusak, dalam menanganinya sebaiknya tidak menggunakan pinset tetapi jari. Sebelum dimasukkan dalam organ bath mesentrerialnya dibersihkan dulu kemudian isi usus dibersihkan dengan cara disemprot rongga ususnya dengan pipet berisi larutab Kreb's, setelah itu benang diikatkan pada kedua ujung ileum.

lleum dimasukkan ke dalam organ bath dengan ujung bawah diikatkan pada tangkai penahan dan ujung atas diikatkan dengan ujung fulcrum/tangkai pada kimograf dengan diberi beban sebesar $1 \mathrm{gram}$. Setelah siap, suhu dalam organ bath diatur setinggi $37^{\circ} \mathrm{C}$ dan terus diaerasi non stop memakai air pump. Preparat ileum diinkubasikan dahulu dalam larutan Kreb's selama 1-2 jam disertai pencucian dengan mengganti larutan kreb's tiap 10-15 menit agar preparat teradaptasi. Pada saat eksperimen dengan ekstrak daun Physalis minima $L$ volume larutan Kreb's harus stabil sebesar $30 \mathrm{ml}$ sehingga tiap kali berkurang harus segera ditambah lagi agar volumenya tetap $(6,8)$.

\section{Cara Kerja Percobaan}

Setelah semua alat dan bahan yang diperlukan untuk penelitian siap, otot polos usus halus terpisah marmut telah diset dan organ bath sudah stabil, dilakukan studi eksplorasi untuk menentukan dosis metakolin dan dosis ekstrak daun Physalis minima L. Setelah didapatkan dosis ekstrak daun Physalis minima $L$ yang efektif menghambat kontraksi otot polos usus halus terpisah marmut yaitu $0,15 \%, 0,30 \%$ dan $0,45 \%$ serta dosis mentakolin yang menimbulkan $80 \%$ efek yaitu dosis 10-5, kemudian sediaan tersebut diberi perlakuan. Stabilisasi dilakukan selama 2 jam dengan penggantian larutan kreb's setiap 10 sampai 15 menit. Setelah stabil sediaan diberi perlakuan sebagai berikut: 
1. Pemberian metakolin $10^{-5}$ tanpa pemberian ekstrak daun Physalis minima $L$. Data yang didapatkan dicatat dan didapatkan data untuk kontrol. Setelah itu, dilakukan pencucian dan stabilisasi ulang selama 2-4 jam.

2. Pemberian ekstrak daun Physalis minima $L$ dosis $0,15 \%$ selama 15 menit untuk memberi kesempatan bagi ekstrak daun Physalis minima $L$ untuk berikatan dengan reseptor. Kemudian ditambahkan metakolin dosis $10^{-5}$ tanpa didahului dengan pencucian. Data yang didapatkan direkam dan kemudian dilakukan stabilisasi lagi.

3. Pemberian ekstrak daun Physalis minima $L$ dosis 0,30\% selama 15 menit untuk memberi kesempatan bagi ekstrak daun Physalis minima $L$ untuk berikatan dengan reseptorl. Kemudian ditambahkan metakolin dosis $10^{-5}$ tanpa didahului dengan pencucian. Data yang di dapatkan direkam dan kemudian dilakukan stabilisasi lagi.

4. Pemberian ekstrak daun Physalis minima $L$ dosis 0,45\% selama 15 menit untuk memberi kesempatan bagi ekstrak daun Physalis minima $L$ untuk berikatan dengan reseptor. Kemudian ditambahkan metakolin dosis $10^{-5}$ tanpa didahului dengan pencucian. Data yang didapatkan direkam dan kemudian dilakukan stabilisasi lagi.

\section{HASIL PENELITIAN}

Data yang diperoleh adalah besarnya kontraksi usus halus terpisah marmut (lihat Tabel 1). Sedangkan hasil ratarata dari besar kontraksi otot polos usus halus dapat dilihat pada gambar 1.

Tabel 1. Hasil pengukuran kontraksi otot polos ususs halus terpisah marmut setelah pemberian ekstrak daun Physalis minima $L$ dengan stimulasi metakolin

\begin{tabular}{ccccc}
\hline \multirow{2}{*}{$\mathrm{N}$} & \multicolumn{4}{c}{ Dosis PM } \\
\cline { 2 - 5 } & $\mathrm{K}$ & $\mathrm{PM} \mathrm{1}$ & $\mathrm{PM} \mathrm{2}$ & $\mathrm{PM} \mathrm{3}$ \\
\hline 1 & 35 & 17,5 & 15,5 & 6 \\
\hline 2 & 31 & 19 & 21,5 & 18 \\
\hline 3 & 52 & 43,5 & 34 & 32 \\
\hline 4 & 59 & 44 & 40,5 & 22,5 \\
\hline 5 & 55 & 42 & 43 & 30 \\
\hline
\end{tabular}

Keterangan:

$\mathrm{PM}=$ Physalis minima $L$

PM $1=$ Physalis minima $L 0,15 \%$

PM 2 = Physalis minima $L 0,30 \%$

PM $3=$ Physalis minima $L 0,45 \%$

$\mathrm{K}=$ Kontrol

$\mathrm{N}=$ Pengulangan
Besar kontraksi otot polos usus halus terpisah marmut dengan stimulasi metakolin 10-5

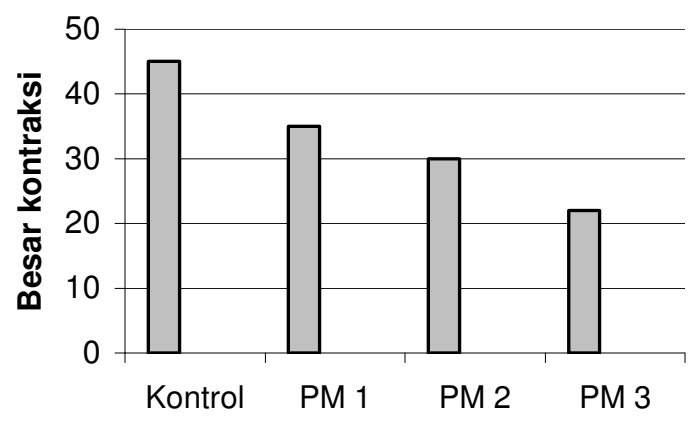

Gambar 1. Diagram Batang Besar Kontraksi Otot Polos Usus Halus Terpisah Marmut Dengan Hambatan Berbagai Dosis Daun Physasis minima L kemudian Distimulasi Dengan Metakolin Dosis $10^{-5}$

Dari data tersebut dilakukan uji parameterik dengan menggunakan program "SPSS 12.0 For Windows". Uji parametrik yang dilakukan adalah one way ANOVA (Analysis Of Variance) dan simpel regresi linear. Dari hasil analisa terlihat bahwa Lacene Test Hitung 0,823 ( $p=0,500)$. ANOVA $p=0,041$. Dari tabel Post Hoc Test terlihat bahwa rata-rata dari kontrol dengan PM $3(0,45 \%)$ berbeda secara nyata sedangkan kontrol dengan PM 1 dan 2 tidak berbeda secara nyata. Begitu juga pada PM 1 dengan PM 2 dan 3 ataupun PM 2 dengan PM 3. Pada Regresi Linear didapatkan $R=-0,608, p=0,02$. Persamaan regresi yang didapatkan adalah $Y=52,150-7,660 x$

\section{DISKUSI}

Ada beberapa dugaan mekanisme yang mendasari terjadinya relaksasi otot polos usus halus dari ekstrak daun Physalis minima L. Salah satu mekanisme yang diduga kuat adalah melalui antagonis reseptor $M_{3}$ karena dalam penelitian sebelumnya telah dibuktikan bahwa daun Physalis minima $L$ mengandung fraksi alkaloid atropin yang menunjukkan harga $\operatorname{Rf}(0,24)$ yang hampir sama dengan standart Belladona (5). Selain itu, reseptor $M_{3}$ merupakan reseptor yang sebarannya paling banyak dalam otot polos usus halus (6).

Aktivasi reseptor $M_{3}$ oleh agonisnya menyebabkan peningkatan aktifitas fosfolipase $\mathrm{C}$ (PLC) dengan perantaraan suatu protein $G$ (yang belum jelas jenisnya). Selanjutnya fosfolipase $C$ akan menghidrolisis fosfatidil inositol 4,5 bifosfat $\left(\mathrm{PIP}_{2}\right)$ sehingga terbentuk Diasil Gliserol 
(DAG serta Inositol 1, 4, 5 trifosfat $\left(\mathrm{IP}_{3}\right)$. IP 3 menyebabkan pelepasan $\mathrm{Ca}^{+}$dari depot intraseluler dan menimbulkan kontraksi otot polos usus halus. DAG dan $\mathrm{IP}_{3}$ merangsang aktivitas protein kinase $C$ sehingga terjadi fosforilasi protein diikuti oleh kontraksi otot polos usus halus (9). Dalam penelitian ini, fraksi $C$ alkaloid atropin daun Physalis minima $L$ diduga sebagai antagonis reseptor $M_{3}$ sehingga respon seluler (kontraksi otot polos usus halus) tidak terjadi.

Selain melalui reseptor $M_{3}$, kemungkinan mekanisme kerja yang lain dari daun Physalis minima $L$ dalam merelaksasikan otot polos usus halus adalah melalui perannya sebagai agonis reseptor $\beta_{2}$ pada membran sel otot polos usus halus, akan tetapi dugaan mekanisme ini masih belum terlalu kuat karena kandungan daun Physalis minima $L$ yang melalui mekanisme ini belum diketahui dengan pasti dan sebaran reseptor $\beta_{2}$ dalam otot polos usus halus relatif sedikit. Penduduk reseptor $\beta_{2}$ pada memebran sel otot polos usus halus oleh agonisnya menyebabkan terbentuknya CAMP di permukaan dalam membran sel. Proses ini meliputi interaksi antara reseptor dengan protein pengatur Gs dan interaksi antara protein pengatur Gs dengan GTP. Interaksi Gs-GTP menimbulkan stimulasi adenilat siklase untuk memproduksi cAMP. Selanjutnya di bawah pengaruh protein kinase A, cAMP menimbulkan penurunan $\mathrm{Ca}^{++}$. Sehingga terjadi relaksasi otot polos usus halus tetapi mekanisme yang pasti belum diketahui (7). Selain itu, steroid pada daun Physalis minima L diduga mempengaruhi sistem enzim melalui protein kinase yang memerlukan siklik AMP pada reseptor $\beta_{2}(10)$.

Selain melalui kedua mekanisme diatas, kemungkinan mekanisme kerja yang lain dari daun Physalis minima $L$ dalam merelaksasikan otot polos usus halus adalah melalui perannya sebagai agonis reseptor $a_{1}$ pada membran sel otot polos usus halus akan tetapi dugaan mekanisme ini juga masih belum terlalu kuat karena kandungan daun Physalis minima $L$ yang melalui mekanisme ini belum diketahui dengan pasti dan sebaran reseptor $a_{1}$ dalam otot polos usus halus relatif sedikit Aktifasi reseptor $a_{1}$ menstimulasi enzim fofolipase $C$ (PLC), yang menghidrolisis fosfatidil inositol difosfat $\left(\mathrm{PIP}_{2}\right)$ menjadi inositol trifosfat $\left(\mathrm{IP}_{3}\right)$ dan diasil gliserol (DAG), melalui suatu protein $\mathrm{G}$ yang belum dikenal. $\mathrm{IP}_{3}$ menstimulasi pelepasan ion $\mathrm{Ca}^{+}+$dari retikulum endoplasmik. Peningkatan kadar $\mathrm{Ca}^{++}$intrasel akan mengaktifkan kanal $\mathrm{K}^{+}$yang bergantung pada $\mathrm{Ca}^{+}+$sehingga terjadi hiperpolarisasi dan relaksasi otot (7).

Ekstrak daun ceplukan juga bisa secara langsung bekerja pada otot polos usus halus yaitu ekstrak daun ceplukan menutup kanal kalsium sehingga $\mathrm{Ca}^{+}{ }^{+}$dari ekstraseluler tidak bisa masuk. Bila konsentrasi ion kalsium intrasel menurun di bawah nilai kritis akan menyebabkan tidak adanya ion kalsium yang berikatan dengan kalmodulin. Hal ini akan mengaktifkan miosin fosfatase, enzim yang terletak di dalam cairan pada sel otot polos, berfungsi untuk menguraikan fosfat dari rantai ringan pengatur. Akibatnya siklus kontraksi berhenti kemudian terjadi relaksasi (9).

Dari uraian diatas, kemungkinan ekstrak daun ceplukan mampu menghambat kontraksi otot polos usus halus melalui berbagai kemungkinan mekanisme kerja yang telah diuraikan atau kombinasi dari berbagai mekanisme tersebut karena ekstrak daun ceplukan mengandung berbagai bahan aktif yang dapat bekerja pada berbagai reseptor atau langsung pada otot polos usus halus sehingga timbul relaksasi usus halus.

Dalam kaitannya dengan pemanfaatan ekstrak daun ceplukan sebagai terapi anti diare kemungkinan ekstrak daun ceplukan berfungsi sebagai obstipansia untuk terapi simtomatis dengan cara menekan peristaltik usus.

Dengan demikian pada penelitian ini terbukti bahwa ekstrak daun ceplukan dapat menghambat kontraksi otot polos usus halus terpisah marmut tetapi tidak diketahui dengan pasti mekanisme kerjanya sehingga perlu dilakukan penelitian lebih lanjut untuk mengetahui secara pasti mekanisme kerja ekstrak daun ceplukan dalam menimbulkan efek penurunan kontraksi otot polos usus halus.

\section{KESIMPULAN}

1. Hipotesis bahwa ekstrak daun ceplukan dapat menghambat kontraksi otot polos usus halus terpisah marmut (Cavia porcellus) telah terbukti.

2. Pemberian ekstrak daun ceplukan pada otot polos usus halus terpisah marmut yang kemudian distimulasi dengan metakolin dapat menurunkan kontraksi otot polos usus halus marmut dimana semakin besar dosis ekstrak daun ceplukan yang diberikan, kontraksi otot polos usus halus terpisah marmut semakin kecil.

\section{DAFTAR KEPUSTAKAAN}

1. Badan Litbangkes Depkes Rl. Profil Kesehatan Indonesia. Online. 1998. http://www.depkes.go.id/IND/DATA/PROFIL/Index.htm. [diakses 12 Februari 2004].

2. Tjay Tan Hoan dan Rahardjo Kirana. Obat-obatan Penting. Edisi 5. Jakarta: PT Elex Media Komput Indo Gramedia; 2002; 277-281.

3. Mulchandani P. Planca Medica Journal of Medicinal Plant Research. Physalin D A New 13,14- seco-16 24-cyclo Steroid From Physalis Minima 1979;37.

4. Cordell GA. Introduction to alkaloid a biogenetic approach. New York: John Wiley and Sons; 1981. 
5. Efendi Magfur. Pengaruh Alkaloid Physalis Minima L Terhadap Penurunan Kontraktilitas Aorta Setelah Pemberian NE Eksogen. [Tugas Akhir]. Malang: Fakultas MIP Universitas Brawijaya; 1998.

6. Gosh MM. Fundamental of Experimental Pharmacology. Calcutta: Scientific Book Agency; 1971.

7. Darmansjah. Obat Otonom. Dalam: Sulistia GG, (eds). Farmakologi dan Terapi. Jakarta: Bagian Farmakologi UI; 1998; 22-26.

8. Martin. Remington's Practice of Pharmacy Easton. Pensylvania: Mack Publishing Company; 1961; 246.

9. Pery WLM. Pharmacologycal Experiments On Isolated Preparation. New York: Churchil Living Stone; 1974; 2.

10. Setiawan. Pengantar Farmakologi. Dalam: Sulistia (eds). Farmakologi dan Terapi. Jakarta: Bagian Farmakologi UI; 1998; $10-23$.

11. Nogrady Thomas. Kimia Medisinal, Pendekatan Secara Biokimia. Bandung: ITB; 1992; 310-311. 
